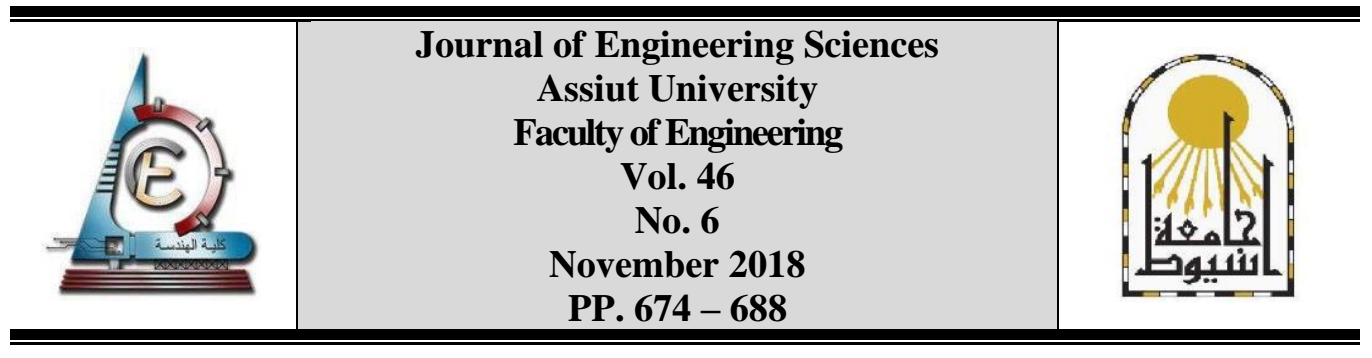

\title{
BEHAVIOURAL INVESTIGATION OF PRESTRESSED CONCRETE BRIDGES HAVING BOX GIRDER WITH THREE CELLS
}

\author{
Abdou Khalaf Mohamed ", Abdel kader A. Haridy, Zakaria H. Awadallah
}

Faculty of Eng. AL Azhar University, Qena, Egypt

Received 2 August 2018; Accepted 14 September 2018

\begin{abstract}
Post-tensioned, pre-stressed bridges are characterized by better stability and performance. The stress distribution in both directions, longitudinal " $\mathrm{X}$ " and transverse " $\mathrm{Y}$ ", of Box-Girder bridges is non-uniform, so it has complex behaviour. Recently there are much software for the design and analysis of bridges. Using software for bridges' design is much better than the manual procedure. This paper involves modelling and analysis of a Box-Girder with three different-shaped, posttensioned cells. Three variable shapes of multi-cell Box-Girders "Vertical-exterior girder, sloppedexterior girder and exterior girder with maximum slope" with the same area and different depths (2, 2.3 and 2.6m) were modelled and analysed using CSI-Bridge program, 2017-version. The analysis is carried under dead load, moving live load (according to the code of loading in Egypt), and prestressed load. Some results such as deflection and longitudinal stress were discussed and analysed.
\end{abstract}

Keywords: Post-tensioned, Multi-cell Box-Girder Bridge, linear analysis.

\section{Introduction}

The Box-Girders are normally used for bridges, flyovers and at grade separators. The main beam of a Bridge's Box-Girder consists of hollow Box-Girders shaped. Usually BoxGirders are made of steel structure, pre-stressed concrete, reinforced concrete or using composite sections. The Box-Girders cross-section may be trapezoidal, square or rectangular. Using of post-tensioned concrete Box-Girders reduce drastically the depth of these girders compared to normal I-girders. Hence, the post-tensioned Box-Girders are suitable for large spans. Also the Box-Girders' depth is affected by webs number.

There are several literature [2, 4, 5, 7 and 8] on bridges having Box-Girders dealing with analytical formulations to understand their behaviour as a complex structural system. Some experimental studies were undertaken to investigate the existence of accurate elastic analysis methods, such as the finite-element method. Also, there are studies involving a single and multi-cell Box-Girders, the investigations of them [2, 4, 5, 7 and 8] deal with using folded-plate elements and box-beam elements.

\footnotetext{
* Corresponding author.

E-mail address: kaderharidy@yahoo.com
} 
Venkata et al [3] investigated the Box-Girder Bridge's response under moving load. They have used FEM-based modelling and analysis software. They, [3], concluded that the performance of multi-cell Box-Girders is good and having high resistance.

Harish M K et al [5] have studied the parametric behaviour of prototype models (BoxGirder Bridges with single and four cells) using CSI-Bridge. The results indicated that a Girder bridge having single cell is more economical than a girder bridge having four cells.

Five Box-Girders of multi-cell and different shapes were considered by Amit Upadhyay et al [6]. Modelling is done by CSI-Bridge program, 2017-version. After analysing all the different shapes of multi-cell Box-Girders, they found that better results were obtained for Box-Girders of exterior girders having slopped sides compared with the other shapes.

\section{Definition}

Three models of multi-cell Box-Girders, among which, a vertical-exterior girder, a slopped-exterior girder and a maximum-slopped girder, were analysed using CSI-Bridge program which depends on the finite-element method. The analysis was carried out for constant deck width and the same area of cross sections. Those Box-Girders were analysed to study and make comparison of those bridges of Box-Girders in terms of deflection and longitudinal stress under loading conditions over length of the span.

The cross sectional views of the Box-Girder Bridges are indicated in table- 1 and Figures-1, 2 and 3 respectively.

- The width of bridge road way $=10.5 \mathrm{~m}$

- Total width $=11 \mathrm{~m}$

- Traffic lanes number $=3 \mathrm{~m}$

- Span length $=30 \mathrm{~m}$

Table 1.

dimensions of tested box girders cross section

\begin{tabular}{|c|c|c|c|c|c|c|c|c|c|}
\hline $\begin{array}{c}\text { Item } \\
(\mathrm{m})\end{array}$ & $\begin{array}{c}\text { Box } \\
\text { with } \\
\text { vertical } \\
\text { Girders }\end{array}$ & $\begin{array}{c}\text { Box } \\
\text { slopped } \\
\text { exterior } \\
\text { girders }\end{array}$ & $\begin{array}{c}\text { Box } \\
\text { exterior } \\
\text { girders } \\
\text { maximum } \\
\text { slopped }\end{array}$ & $\begin{array}{c}\text { Box } \\
\text { with } \\
\text { vertical } \\
\text { Girders }\end{array}$ & $\begin{array}{c}\text { Box } \\
\text { slopped } \\
\text { exterior } \\
\text { girders }\end{array}$ & $\begin{array}{c}\text { Box } \\
\text { exterior } \\
\text { girders } \\
\text { maximum } \\
\text { slopped }\end{array}$ & $\begin{array}{c}\text { Box } \\
\text { With } \\
\text { vertical } \\
\text { Girders }\end{array}$ & $\begin{array}{c}\text { Box } \\
\text { slopped } \\
\text { exterior } \\
\text { girders }\end{array}$ & $\begin{array}{c}\text { Box } \\
\text { exterior } \\
\text { girders } \\
\text { maximum } \\
\text { slopped }\end{array}$ \\
\hline Width & \multicolumn{3}{|c|}{11} & \multicolumn{3}{|c|}{11} & \multicolumn{3}{|c|}{11} \\
\hline Depth & \multicolumn{3}{|c|}{2.3} & \multicolumn{3}{|c|}{2.6} \\
\hline $\mathrm{t}_{1}$ & 0.3 & 0.3 & 0.3 & 0.3 & 0.3 & 0.3 & 0.3 & 0.3 & 0.3 \\
\hline $\mathrm{t}_{2}$ & 0.3 & 0.3 & 0.3 & 0.3 & 0.3 & 0.3 & 0.3 & 0.3 & 0.3 \\
\hline $\mathrm{t}_{3}$ & 0.3 & 0.4 & 0.608 & 0.3 & 0.375 & 0.358 & 0.3 & 0.579 & 0.534 \\
\hline $\mathrm{t}_{4}$ & 0.3 & 0.3 & 0.3 & 0.3 & 0.3 & 0.3 & 0.3 & 0.3 & 0.3 \\
\hline $\mathrm{L}_{1}$ & 2.05 & 1.15 & 0.75 & 2.05 & 1.08 & 0.55 & 2.05 & 1.02 & 0.4 \\
\hline $\mathrm{L}_{2}$ & 2.05 & 1.15 & 0.75 & 2.05 & 1.08 & 0.55 & 2.05 & 1.02 & 0.4 \\
\hline $\mathrm{L}_{3}$ & - & 1.5 & 3.0 & - & 1.5 & 3.3 & - & 1.5 & 3.4 \\
\hline
\end{tabular}

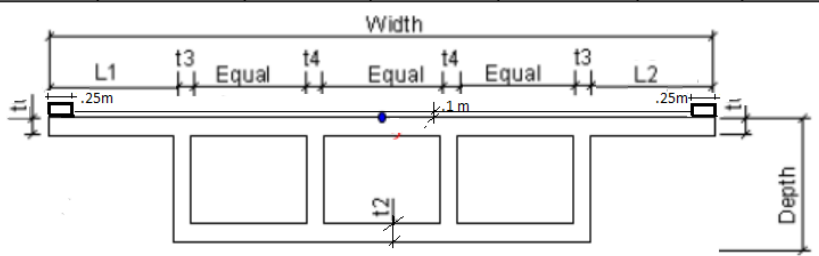

Fig. 1. Cross-sectional details of box with vertical exterior girders 


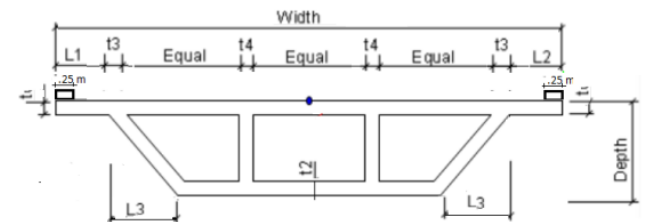

Fig. 2. Cross-sectional details of box with slopped exterior girders

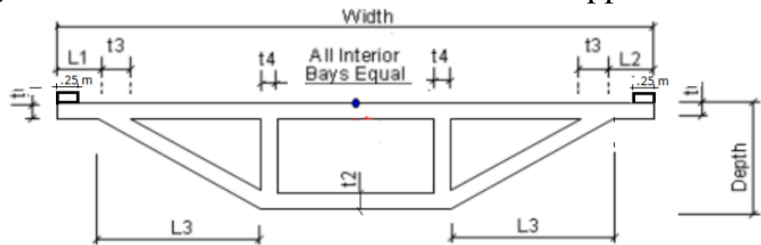

Fig. 3. Cross-sectional details of Box exterior girders with maximum slopped

\section{Material properties}

The box girder considered here for the analysis is prestressed concrete box girder. The material properties are given as following:

Weight /unit volume

Young's modulus $(\mathrm{E})$

Poisson's ratio (v)

Shear Modulus $(\mathrm{G})$

Thermal expansion coefficient (A)

Specific compressive strength of concrete (fc')
$25 \mathrm{KN} / \mathrm{m}^{3}$

$32500\left(\mathrm{~N} / \mathrm{mm}^{2}\right)$

0.15

$1.413 \times 10^{4} \mathrm{~N} / \mathrm{mm}^{2}$

$1.17 \times 10^{-5} / 0 \mathrm{C}$

$40 \mathrm{~N} / \mathrm{mm}^{2}$

\section{Loading}

The loads considered, which are on the superstructure of the bridge Box-Girder are listed below:

- Dead load "DL"; the self-weight of the structure.

- Superimposed dead load "DL": the load from wearing coat and crash barriers.

- Moving load; the live load "LL" is considered as Egyptian code loading. Figure-8 shows the applied tracked vehicle loading on the Box-Girder.

- Pre-stressed load "P"; the pre-stressing tendons provide clamping force which produces compressive stress to balance the tensile stress experienced by the concrete due to bending load.

- Tendon Properties:

- Tendon profile: Parabolic

- Pre-stressing Strand: $\phi 15.2 \mathrm{~mm}-0.6$ strand

- Ultimate Strength: $\mathrm{f}_{\mathrm{pu}}=1.86326 \times 10^{6} \mathrm{kN} / \mathrm{m}^{2}$

- Cross Sectional area of each tendon $=2800 \mathrm{~mm}^{2}$

- Elastic modulus: $\mathrm{E}_{\mathrm{ps}}=2 \times 10^{8} \mathrm{kN} / \mathrm{m}^{2}$

- Jacking stress $=0.75 f_{\mathrm{pu}}=1395 \mathrm{~N} / \mathrm{mm}^{2}$ 

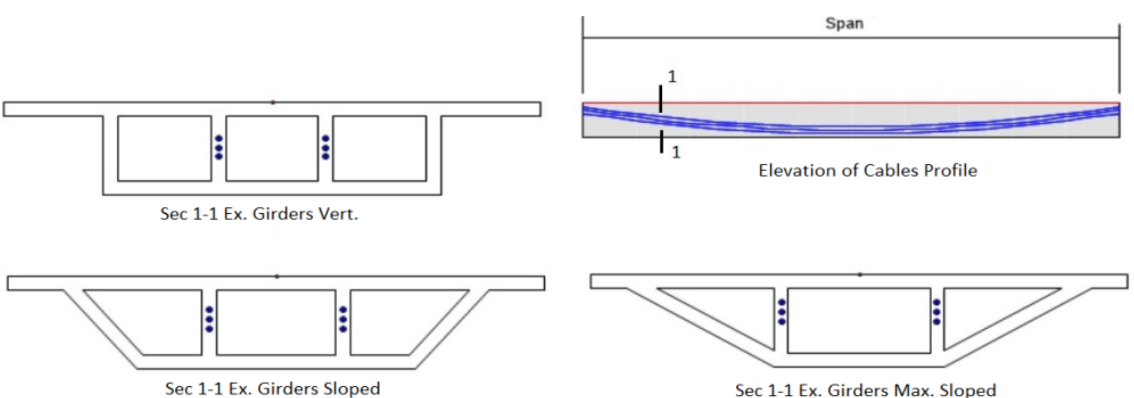

Fig. 4. Prsetressing details

\section{Methodology}

- Modelling and analysis of three models; rectangular with vertical-exterior girder, trapezoidal with slopped-exterior girder, and trapezoidal with exterior girder maximum slopped for dead load. Moving load and pre-stressed load are performed, the longitudinal stresses at the top cord and bottom cord of the girder's cross sections, bending moment, and deflection under all loading conditions, are recorded.

-The responses of the three Box-Girders models are compared.

- Figure-5 to figure-7 show the full view of Box-Girders models and figure- 8 shows the vehicle loading arrangement.

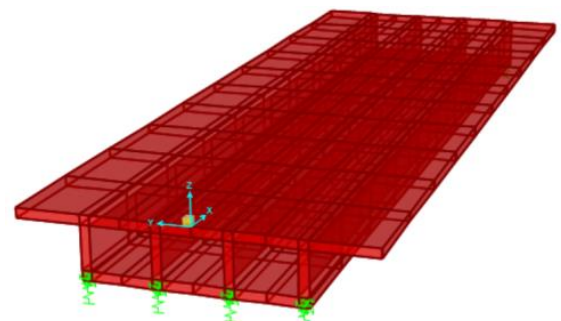

Fig. 5. Box girder with vertical exterior girders modelled in CSI Bridge program

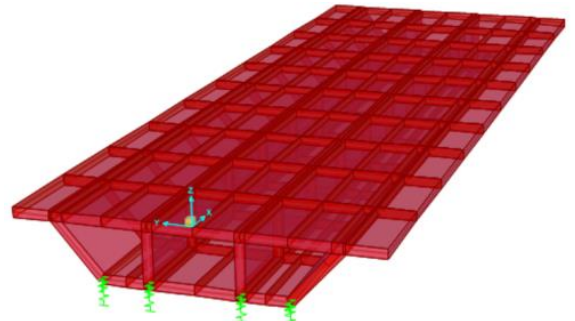

Fig. 6. Box girder with slopped exterior girders modelled in CSI Bridge program

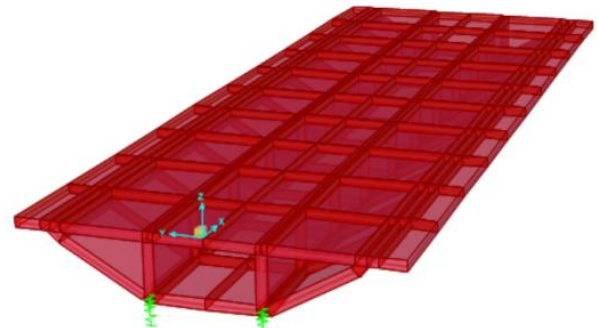

Fig. 7. Box girder with maximum slopped exterior girders modelled in CSI Bridge program 


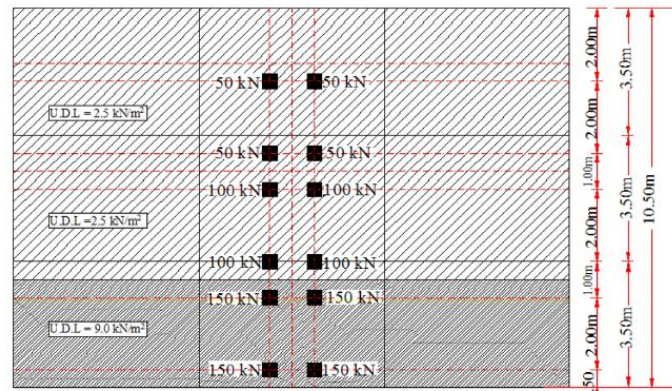

Fig. 8. Loading according to Egyptian Code 2012 [1] (span 30, road way width $10.5 \mathrm{~m}$ ).

\section{Results and discussions}

A multi-cell Box-Girder, rectangular, trapezoidal with slopped exterior girders, and trapezoidal with exterior girders maximum slopped are analysed and the curves of deflection and longitudinal stress of the three models under different load combinations are presented.

\subsection{The deflection (for two meter depth box girders)}

Figures-9, 10 and 11 show the deflection along the span length for two meter depth Box- Girders, rectangular (Vert.), trapezoidal (Sloped) and trapezoidal (Max sloped) under dead loads, pre-stressing loads and moving live loads respectively. It is observed that the deflection along the span is the least for rectangular hollow girder under all loading conditions. The maximum deflections at mid-span of the rectangular hollow girder is 20.7\% and 7.38\% lower than the Trapezoidal (Max sloped) and Trapezoidal (Sloped) hollow girder sections respectively under "DL" as shown in figure-9. Under pre-stressing loading "P", figure-10 shows that the maximum camber at mid span of rectangular (Vert.) Box-Girder is $32.34 \%$ and $11.41 \%$ lower than trapezoidal (Max sloped) and trapezoidal (Sloped) Box-Girder sections respectively. From the other hand, the maximum deflection at mid span of rectangular (Vert.) Box-Girder is $10.9 \%$ and 3.4\% lower than the Trapezoidal (Max sloped) and Trapezoidal (sloped) box girder sections respectively under $(\mathrm{DL}+\mathrm{P}+\mathrm{LL})$ as shown in figure-11. The max deflection, and camper at mid span under different case of loading are given in Table- 2 .

Table 2.

Comparison of maximum deflection at mid span for two meter depth box girders.

\begin{tabular}{|c|c|c|c|}
\hline Section & Deflection $(\mathrm{mm})(\mathrm{DL})$ & Camber $(\mathrm{mm}) \quad(\mathrm{P})$ & $\begin{array}{c}\text { Deflection }(\mathrm{mm}) \\
(\mathrm{DL}+\mathrm{P}+\mathrm{LL})\end{array}$ \\
\hline Vertical & 18.080 & 10.401 & 17.75 \\
\hline Sloped & 19.52 & 11.74 & 18.38 \\
\hline Max. sloped & 22.80 & 15.37 & 19.93 \\
\hline
\end{tabular}




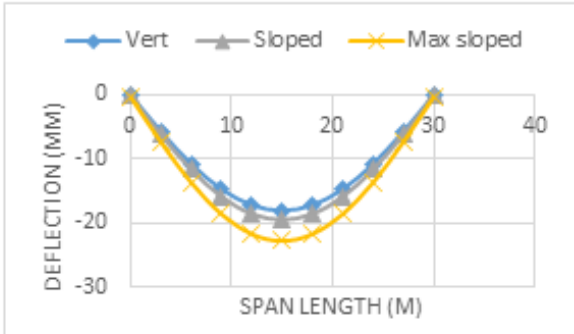

Fig. 9. Variation of deflection along the span under (DL) for $2.0 \mathrm{~m}$ depth

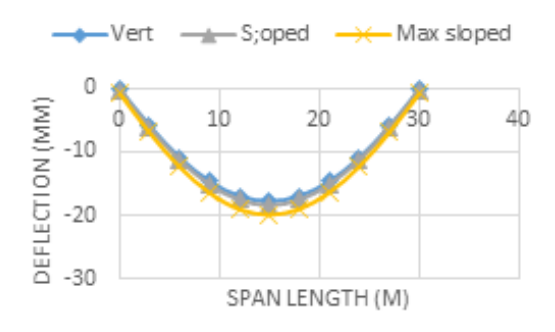

Fig. 11. Variation of deflection along the span under $(\mathrm{DL}+\mathrm{P}+\mathrm{LL})$ for $2.0 \mathrm{~m}$ depth

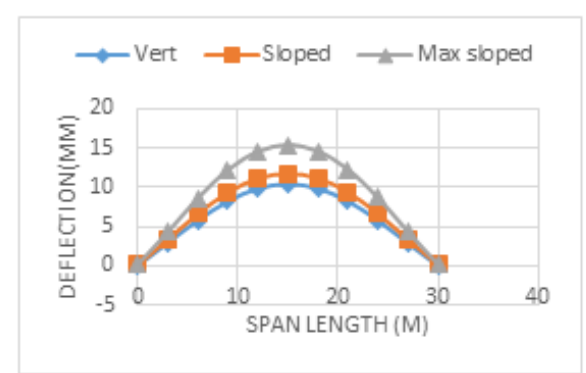

Fig. 10. Variation of deflection along the span under prestressing load $(\mathrm{P})$ for $2.0 \mathrm{~m}$ depth

\subsection{Longitudinal stress top and bottom of central part of cross section (for two meter depth box girders)}

Maximum stress at the bottom flange for two-meter-depth Box-Girders, Rectangular (Vert.), Trapezoidal (Sloped) and Trapezoidal (Max sloped) under dead load, pre-stressing load and moving live load. The longitudinal stress in the top and bottom flange is least for rectangular hollow girder under all loading conditions.

The maximum longitudinal stress at mid-span of rectangular (Vert.) Box-Girder is lower than Trapezoidal (Max sloped) Box-Girder and Trapezoidal (Sloped) Box-Girder by $11.26 \%, 5.85 \%$ in top flange and $28.76 \%, 12.28 \%$ in the bottom flange respectively under dead load (DL).

The maximum longitudinal stress at mid-span of rectangular (Vert.) Box-Girder is lower than that of the trapezoidal (Max sloped) Box-Girder and trapezoidal (Sloped) BoxGirder by $71.1 \%$ and $40.56 \%$ in top flange and $24.89 \%$ and $8.1 \%$ in the bottom flange respectively under pre-stressing load " $\mathrm{P}$ ".

Also the maximum longitudinal stress at mid-span of rectangular (Vert.) Box-Girder is lower than that of the trapezoidal (Max sloped) Box-Girder and trapezoidal (Sloped) BoxGirder by $1.2 \%$ and $1.9 \%$ in top flange and $33.9 \%, 16.8 \%$ in bottom flange respectively under $(\mathrm{DL}+\mathrm{P}+\mathrm{LL})$.

The variation of longitudinal stress at top and bottom of the centre part of the cross section under all previous loading conditions are shown in Figures 12 to 17. 
JES, Assiut University, Faculty of Engineering, Vol. 46, No. 6, November 2018, pp.674-688

Table 3.

Comparison of maximum longitudinal stress at mid span for box girders having two meter in depth

\begin{tabular}{|c|c|c|c|c|c|c|}
\hline \multirow{2}{*}{ Section } & \multicolumn{2}{|c|}{ (DL) } & \multicolumn{2}{c|}{ Prestressing (P) } & \multicolumn{2}{c|}{ (DL+P+LL) } \\
\cline { 2 - 7 } & $\begin{array}{c}\text { Max Stress } \\
\text { top (MPA) }\end{array}$ & $\begin{array}{c}\text { Max Stress } \\
\text { bottom } \\
\text { (MPA) }\end{array}$ & $\begin{array}{c}\text { Max Stress } \\
\text { top (MPA) }\end{array}$ & $\begin{array}{c}\text { Max Stress } \\
\text { bottom } \\
\text { (MPA) }\end{array}$ & $\begin{array}{c}\text { Max Stress } \\
\text { top (MPA) }\end{array}$ & $\begin{array}{c}\text { Max Stress } \\
\text { bottom } \\
\text { (MPA) }\end{array}$ \\
\hline Vert. & -4.683 & 6.314 & 0.315 & -7.03 & -7.22 & 3.141 \\
\hline Sloped & -4.974 & 7.198 & 0.53 & -7.65 & -7.358 & 3.777 \\
\hline Max Sloped & -5.277 & 8.864 & 1.09 & -9.36 & -7.308 & 4.752 \\
\hline
\end{tabular}

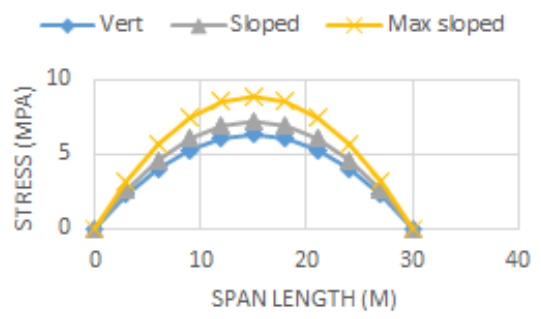

Fig. 12. Variation of longitudinal stress bottom flange along the span under DL for $2.0 \mathrm{~m}$ depth

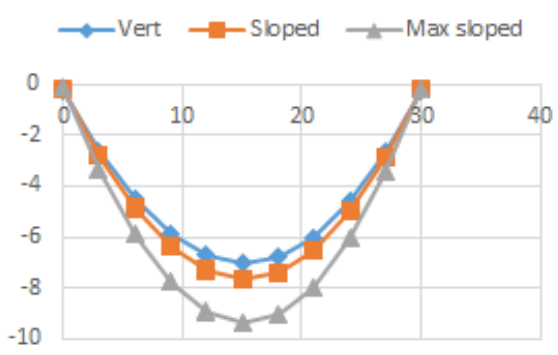

Fig. 14. Variation of longitudinal stress bottom flange along the span under (P) for $2.0 \mathrm{~m}$ depth

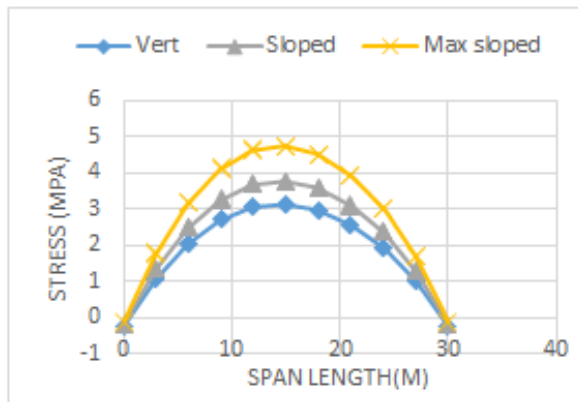

Fig. 16. Variation of longitudinal stress bottom flange along the span under (DL+P+ L) for $2.0 \mathrm{~m}$ depth

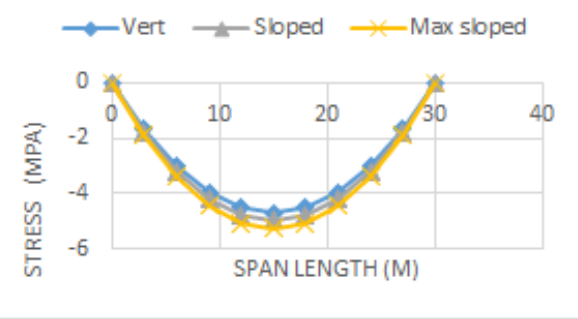

Fig. 13. Variation of longitudinal stress at top flange along the span under DL for $2.0 \mathrm{~m}$ depth

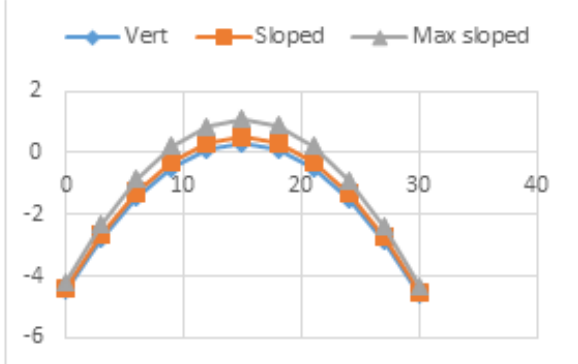

Fig. 15. Variation of longitudinal stress at top flange along the span under $(P)$ for $2.0 \mathrm{~m}$ depth

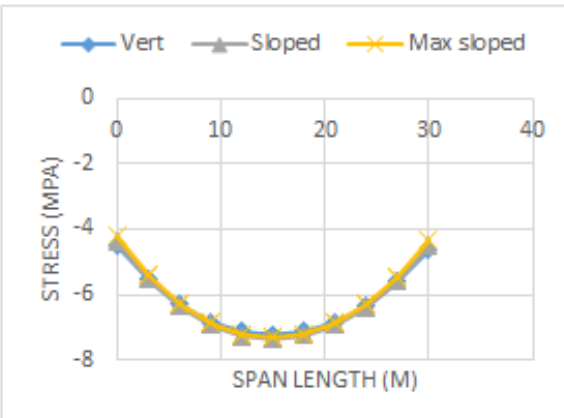

Fig. 17. Variation of longitudinal stress at top flange along the span under (DL+P+ $\mathrm{L}$ ) for $2.0 \mathrm{~m}$ depth

\subsection{Effect of depth variation on deflection and stresses of hollow girder bridges}

The following figures, 18 to 47, show the comparison of the Rectangular (Vert.), Trapezoidal (Sloped) and Trapezoidal (Max sloped) hollow girder bridges subjected to 
dead load, pre-stressing load and Moving Egyptian Live loading (Centrally placed) in terms of deflections and longitudinal bending stress at top and bottom flange of hollow girders with depths of $2 \mathrm{~m}, 2.3 \mathrm{~m}$ and $2.6 \mathrm{~m}$.

\subsubsection{Rectangular (Vert) box girder}

The maximum deflection and maximum bending stress at top and bottom flange of rectangular box girder with different depths due to dead load, prestressing load and moving live load are included in Table - 4.

In Rectangular (Vert) box girder due to dead load, the maximum mid-span deflection is decreases by $31.9 \%$ and $39.7 \%$ for depth of $2.3 \mathrm{~m}$ and $2.6 \mathrm{~m}$ respectively compared to box girder with $2 \mathrm{~m}$ depth. The maximum mid-span bending stress at top of the box girder is decreases by $14.3 \%$ and $24.7 \%$ for depth of $2.3 \mathrm{~m}$ and $2.6 \mathrm{~m}$ respectively compared to box girder with $2 \mathrm{~m}$ depth. Also the maximum mid-span bending stress at bottom of the box girder is decreases by $15.0 \%$ and $25.96 \%$ for depth of $2.3 \mathrm{~m}$ and $2.6 \mathrm{~m}$ respectively compared to box girder with $2 \mathrm{~m}$ depth. On the other hand due to prestressing load $(\mathrm{P})$, the maximum mid-span deflection is decreases by $13 \%$ and $23.87 \%$ for depth of $2.3 \mathrm{~m}$ and 2.6 $\mathrm{m}$ respectively compared to box girder with $2 \mathrm{~m}$ depth. However, the maximum mid-span bending stress at top of box girder is increases by $45.5 \%$ and $79.4 \%$ for depth of $2.3 \mathrm{~m}$ and $2.6 \mathrm{~m}$ respectively compared to box girder with $2 \mathrm{~m}$ depth. But the maximum mid-span bending stress at bottom of the box girder is decreases by $2.2 \%$ and $5.1 \%$ for depth of 2.3 $\mathrm{m}$ and $2.6 \mathrm{~m}$ respectively compared to box girder with $2 \mathrm{~m}$ depth.

Considering of (DL+P+LL), the maximum mid-span deflection is decreases by $33.8 \%$ and $54.17 \%$ for depth of $2.3 \mathrm{~m}$ and $2.6 \mathrm{~m}$ respectively compared to box girder with $2 \mathrm{~m}$ depth. However, the maximum mid-span bending stress at top of box girder is increased by $18.3 \%$ and $31.7 \%$ for depth of $2.3 \mathrm{~m}$ and $2.6 \mathrm{~m}$ respectively compared to box girder with $2 \mathrm{~m}$ depth. But the maximum mid-span bending stress at bottom of box girder is decreases by $47.7 \%$ and $79.98 \%$ for depth of $2.3 \mathrm{~m}$ and $2.6 \mathrm{~m}$ respectively compared to box girder with $2 \mathrm{~m}$ depth.

Table 4.

Comparison of rectangular box section

\begin{tabular}{|c|c|c|c|c|c|c|c|c|c|}
\hline \multirow{3}{*}{ Depth } & \multicolumn{3}{|c|}{ Maximum Deflection (mm) } & \multicolumn{5}{c|}{ Maximum bending Stresses (MPA) } \\
\cline { 5 - 10 } & \multicolumn{3}{|c|}{} & \multicolumn{2}{|c|}{ (DL) } & \multicolumn{2}{c|}{ Prestressing (P) } & \multicolumn{2}{|c|}{ (DL+P+LL) } \\
\cline { 2 - 9 } & $(\mathrm{DL})$ & $(\mathrm{P})$ & $(\mathrm{DL}+\mathrm{P}+\mathrm{LL})$ & $\begin{array}{c}\text { Top } \\
\text { Stress }\end{array}$ & $\begin{array}{c}\text { Bottom } \\
\text { Stress }\end{array}$ & $\begin{array}{c}\text { Top } \\
\text { Stress }\end{array}$ & $\begin{array}{c}\text { Bottom } \\
\text { Stress }\end{array}$ & $\begin{array}{c}\text { Top } \\
\text { Stress }\end{array}$ & $\begin{array}{c}\text { Bottom } \\
\text { Stress }\end{array}$ \\
\hline 2.0 & 17.57966 & 10.40173 & 17.75979 & -4.683 & 6.314 & 0.315 & -7.033 & -7.219 & 3.141 \\
\hline 2.3 & 11.98285 & 9.048863 & 11.75629 & -4.011 & 5.365 & 0.458 & -6.841 & -5.889 & 1.647 \\
\hline 2.6 & 10.60688 & 7.937875 & 8.141316 & -3.526 & 4.675 & 0.565 & -6.648 & -4.929 & 0.634 \\
\hline
\end{tabular}

\subsubsection{Trapezoidal (sloped) box girder}

The maximum deflection and maximum bending stress at top and bottom flange of trapezoidal (sloped) box girder with different depths due to dead load, prestressing load and moving live load are included in Table -5 .

In trapezoidal (sloped) box girder due to dead load, the maximum mid-span deflection is decreases by $36.7 \%$ and $51.0 \%$ for depth of $2.3 \mathrm{~m}$ and $2.6 \mathrm{~m}$ respectively of that for box girder with $2 \mathrm{~m}$ depth. The maximum mid-span bending stress at top of box girder is 
decreases by $21.9 \%$ and $25.5 \%$ for depth of $2.3 \mathrm{~m}$ and $2.6 \mathrm{~m}$ respectively of that for box girder with $2 \mathrm{~m}$ depth, Also the maximum mid-span bending stress at bottom of box girder is decreases by $15.0 \%$ and $27.8 \%$ for depth of $2.3 \mathrm{~m}$ and $2.6 \mathrm{~m}$ respectively of that for box girder with $2 \mathrm{~m}$ depth. On the other hand due to prestressing load (P), the maximum midspan deflection of box girder is decreases by $14.8 \%$ and $24 \%$ for depth of $2.3 \mathrm{~m}$ and $2.6 \mathrm{~m}$ respectively of that for box girder with $2 \mathrm{~m}$ depth. However, the maximum mid-span bending stress at top of box girder is increases by $11.4 \%$ and $34.5 \%$ for depth of $2.3 \mathrm{~m}$ and $2.6 \mathrm{~m}$ respectively of that for box girder with $2 \mathrm{~m}$ depth. But the maximum mid span bending stress at bottom of the box girder is decreases by $3.8 \%$ and $3.9 \%$ for depth of 2.3 $\mathrm{m}$ and $2.6 \mathrm{~m}$ respectively of that for box girder with $2 \mathrm{~m}$ depth.

Considering of (DL+P+LL), the maximum mid-span deflection is decreases by $34.7 \%$ and $56.9 \%$ for depth of $2.3 \mathrm{~m}$ and $2.6 \mathrm{~m}$ respectively of that for box girder with $2 \mathrm{~m}$ depth. However, the maximum mid-span bending stress at top of box girder is increased by $18.8 \%$ and $32.2 \%$ for depth of $2.3 \mathrm{~m}$ and $2.6 \mathrm{~m}$ respectively of that for box girder with $2 \mathrm{~m}$ depth. But the maximum mid-span bending stress at bottom of box girder is decreases by $45.6 \%$ and $83.8 \%$ for depth of $2.3 \mathrm{~m}$ and $2.6 \mathrm{~m}$ respectively of that for box girder with $2 \mathrm{~m}$ depth.

Table 5.

Comparison of trapezoidal (sloped) box girder

\begin{tabular}{|c|c|c|c|c|c|c|c|c|c|}
\hline \multirow{3}{*}{ Depth } & \multicolumn{4}{|c|}{ Maximum Deflection (mm) } & \multicolumn{5}{|c|}{ Maximum bending Stresses (MPA) } \\
\cline { 5 - 10 } & \multicolumn{3}{|c|}{} & \multicolumn{2}{|c|}{ (DL) } & \multicolumn{2}{c|}{ Prestressing (P) } & \multicolumn{2}{c|}{ (DL+P+LL) } \\
\cline { 2 - 10 } & (DL) & (P) & (DL+P+LL) & $\begin{array}{c}\text { Top } \\
\text { Stress }\end{array}$ & $\begin{array}{c}\text { Bottom } \\
\text { Stress }\end{array}$ & $\begin{array}{c}\text { Top } \\
\text { Stress }\end{array}$ & $\begin{array}{c}\text { Bottom } \\
\text { Stress }\end{array}$ & $\begin{array}{c}\text { Top } \\
\text { Stress }\end{array}$ & $\begin{array}{c}\text { Bottom } \\
\text { Stress }\end{array}$ \\
\hline 2.0 & 22.8082 & 11.74152 & 18.37993 & -4.974 & 7.198 & 0.53 & -7.654 & -7.358 & 3.777 \\
\hline 2.3 & 14.44692 & 9.996054 & 11.99814 & -4.234 & 6.019 & 0.632 & -7.366 & -5.978 & 2.048 \\
\hline 2.6 & 11.2087 & 8.926902 & 7.921228 & -3.705 & 5.175 & 0.713 & -7.351 & -4.984 & 0.61 \\
\hline
\end{tabular}

\subsubsection{Trapezoidal (Max sloped) box girder}

The maximum deflection and maximum bending stress at top and bottom flange of trapezoidal (max sloped) box girder with different depths due to dead load, prestressing load and moving live load are included in Table - 6 .

In Trapezoidal (Max sloped) box girder due to dead load, the maximum mid-span deflection of box girder is decreases by $29.9 \%$ and $45.8 \%$ for depth of $2.3 \mathrm{~m}$ and $2.6 \mathrm{~m}$ respectively compared to box girder with $2 \mathrm{~m}$ depth. The maximum mid-span bending stress at top of box girder is decreases by $14.2 \%$ and $25.3 \%$ for depth of $2.3 \mathrm{~m}$ and $2.6 \mathrm{~m}$ respectively compared to box girder with $2 \mathrm{~m}$ depth. Also the maximum mid-span bending stress at bottom of box girder is decreases by $14.22 \%$ and $26.6 \%$ for depth of $2.3 \mathrm{~m}$ and $2.6 \mathrm{~m}$ respectively compared to box girder with $2 \mathrm{~m}$ depth.

On the other hand due to prestressing load $(\mathrm{P})$, the maximum mid-span deflection is decreases by $12.1 \%$ and $24.87 \%$ for depth of $2.3 \mathrm{~m}$ and $2.6 \mathrm{~m}$ respectively compared to box girder with $2 \mathrm{~m}$ depth. However, the maximum mid-span bending stress at top of box girder is increases by $15.9 \%$ and $15.25 \%$ for depth of $2.3 \mathrm{~m}$ and $2.6 \mathrm{~m}$ respectively compared to box girder with $2 \mathrm{~m}$ depth. But the maximum mid-span bending stress at bottom of the box girder is decreases by $1.3 \%$ and $6.3 \%$ for depth of $2.3 \mathrm{~m}$ and $2.6 \mathrm{~m}$ respectively compared to box girder with $2 \mathrm{~m}$ depth. Considering of (DL+P+LL), the 
683

Abdel kader A. Haridy et al., Behavioural investigation of prestressed concrete bridges having .......

maximum mid-span deflection is decreases by $35.5 \%$ and $57 \%$ for depth of $2.3 \mathrm{~m}$ and 2.6 $\mathrm{m}$ respectively of that for box girder with $2 \mathrm{~m}$ depth. However, the maximum mid-span bending stress at top of box girder is increased by $20.3 \%$ and $34.1 \%$ for depth of $2.3 \mathrm{~m}$ and $2.6 \mathrm{~m}$ respectively of that for box girder with $2 \mathrm{~m}$ depth. But the maximum mid-span bending stress at bottom of box girder is decreases by $40 \%$ and $73.9 \%$ for depth of $2.3 \mathrm{~m}$ and $2.6 \mathrm{~m}$ respectively of that for box girder with $2 \mathrm{~m}$ depth.

\section{Table 6.}

Comparison of trapezoidal (max sloped) box girder

\begin{tabular}{|c|c|c|c|c|c|c|c|c|c|}
\hline \multirow{3}{*}{ Depth } & \multirow{2}{*}{\multicolumn{3}{|c|}{ Maximum Deflection (mm) }} & \multicolumn{6}{|c|}{ Maximum bending Stresses (MPA) } \\
\hline & & & & \multicolumn{2}{|c|}{ (DL) } & \multicolumn{2}{|c|}{ Prestressing (P) } & \multicolumn{2}{|c|}{$(\mathrm{DL}+\mathrm{P}+\mathrm{LL})$} \\
\hline & (DL) & (P) & $(\mathrm{DL}+\mathrm{P}+\mathrm{LL})$ & $\begin{array}{c}\text { Top } \\
\text { Stress } \\
\end{array}$ & $\begin{array}{l}\text { Bottom } \\
\text { Stress } \\
\end{array}$ & $\begin{array}{c}\text { Top } \\
\text { Stress }\end{array}$ & $\begin{array}{l}\text { Bottom } \\
\text { Stress } \\
\end{array}$ & $\begin{array}{c}\text { Top } \\
\text { Stress }\end{array}$ & $\begin{array}{l}\text { Bottom } \\
\text { Stress } \\
\end{array}$ \\
\hline 2.0 & 24.64172 & 15.36564 & 19.9252 & -5.277 & 8.864 & 1.088 & -9.367 & -7.308 & 4.752 \\
\hline 2.3 & 17.27508 & 13.51921 & 12.84697 & -4.527 & 7.618 & 1.261 & -9.246 & -5.82 & 2.67 \\
\hline 2.6 & 13.35551 & 11.55077 & 8.569623 & -3.941 & 6.502 & 1.254 & -8.778 & -4.815 & 1.24 \\
\hline
\end{tabular}

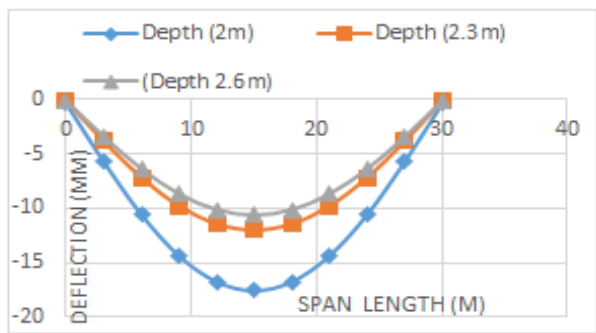

Fig. 18. Comparison of deflection in rectangular hollow girder under (DL)

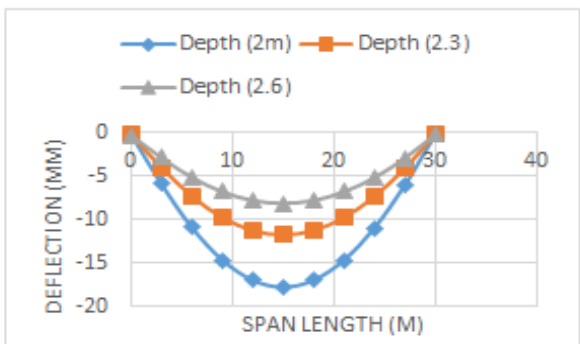

Fig. 20. Comparison of deflection in rectangular hollow girder under $(\mathrm{DL}+\mathrm{P}+\mathrm{LL})$

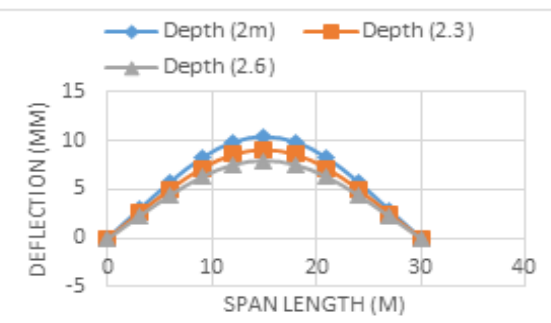

Fig. 19. Comparison of deflection in rectangular hollow girder under prestressing load $(\mathrm{P})$

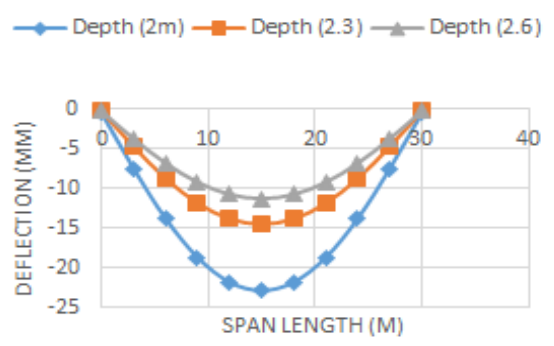

Fig. 21. Comparison of deflection (Sloped) hollow girder under (DL) 


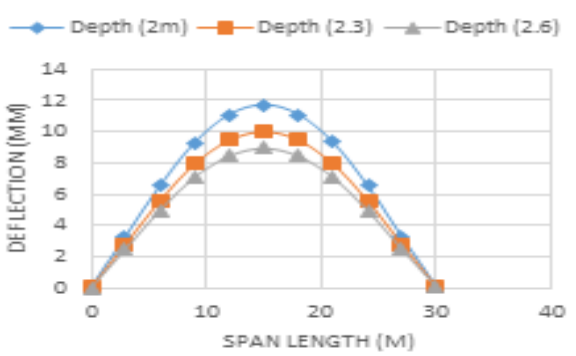

Fig. 22. Comparison of deflection (Sloped) hollow girder under Prestressing (P)

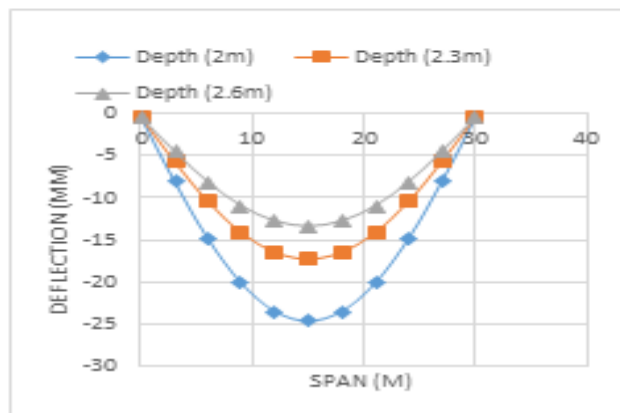

Fig. 24. Comparison of deflection (Max Sloped) hollow girder under (DL)

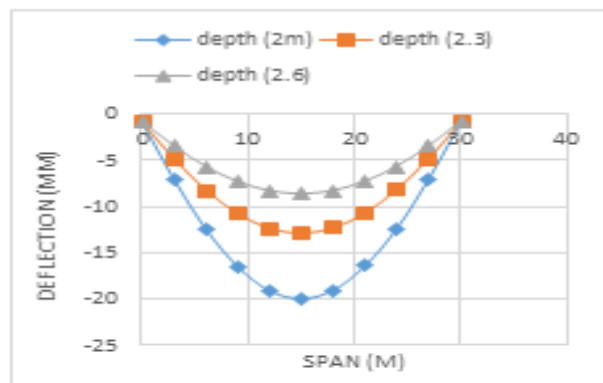

Fig. 26. Comparison of deflection (Max Sloped) hollow girder under $(D L+P+L L)$

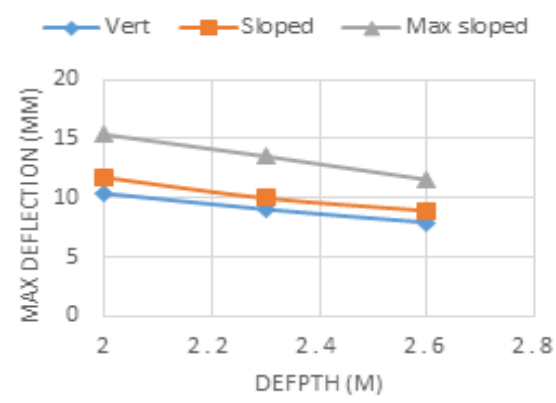

Fig. 28. Maximum deflection at mid span under (P) against depth of hollow girders

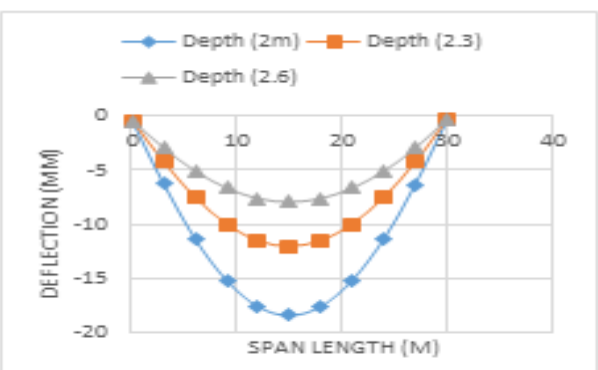

Fig. 23. Comparison of deflection (Sloped) hollow girder under $(\mathrm{DL}+\mathrm{P}+\mathrm{LL})$

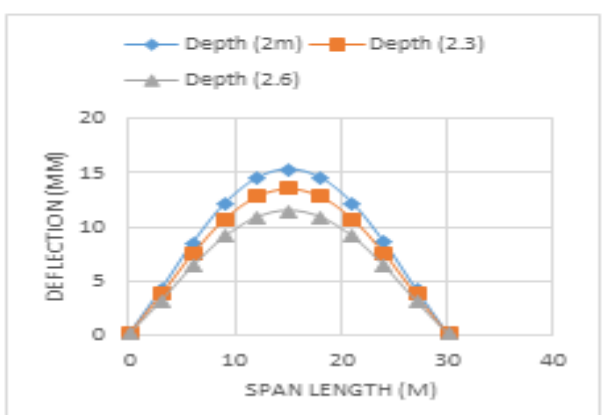

Fig. 25. Comparison of deflection ( Max Sloped) hollow girder under Prestressing (P)

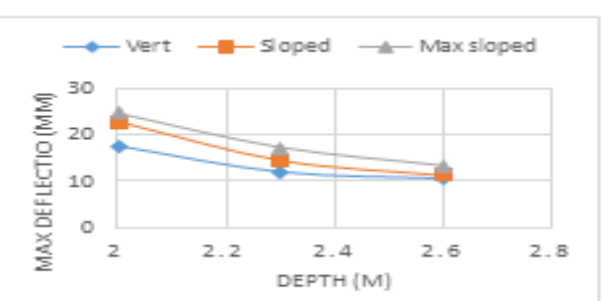

Fig. 27. Maximum deflection at mid span under (DL) against depth of hollow girders

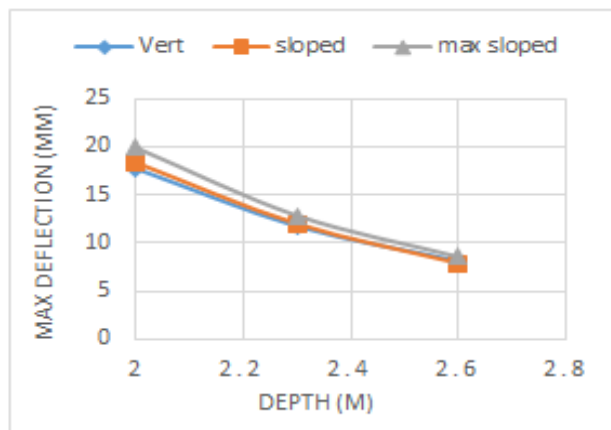

Fig. 29. Maximum deflection at mid span under $(\mathrm{DL}+\mathrm{P}+\mathrm{LL})$ against depth of hollow girders 


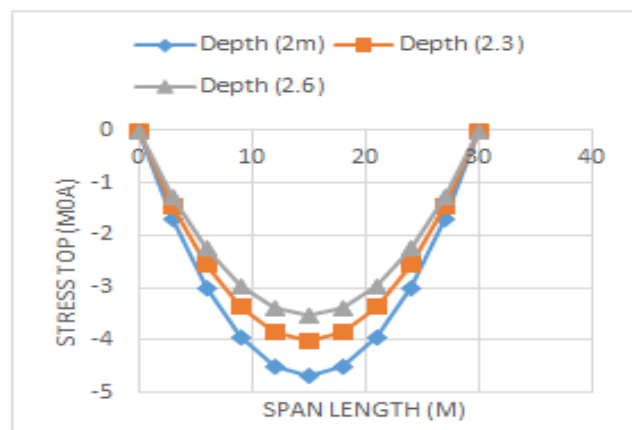

Fig. 30. Comparison of longitudinal stress at top flange for the rectangular hollow girder under (DL)

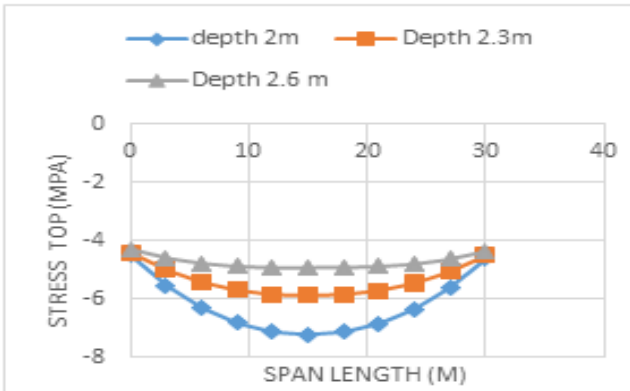

Fig. 32. Comparison of longitudinal stress at top flange for the Rectangular hollow girder under (DL+P+LL)

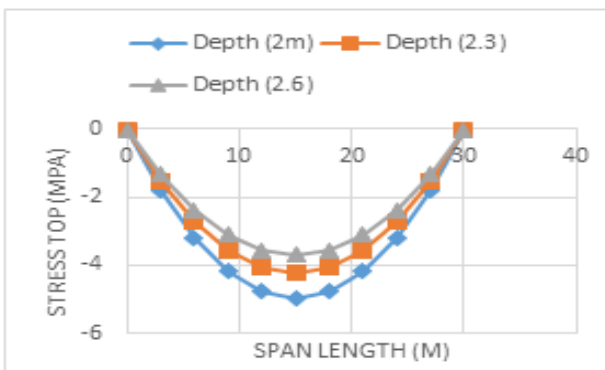

Fig. 34. Comparison of longitudinal stress at top flange of the (Sloped) hollow girder under (DL)

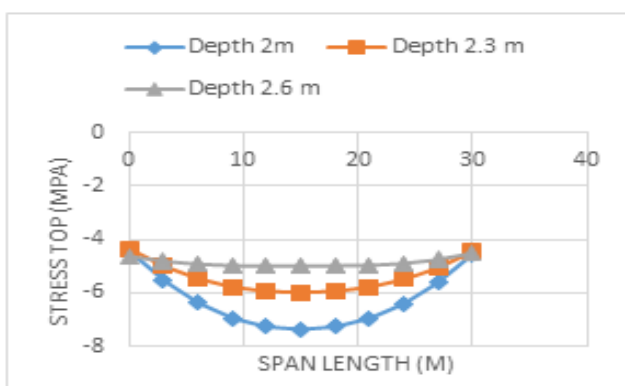

Fig. 36. Comparison of longitudinal stress at top flange of the (Sloped) hollow girder under (DL+P+LL)

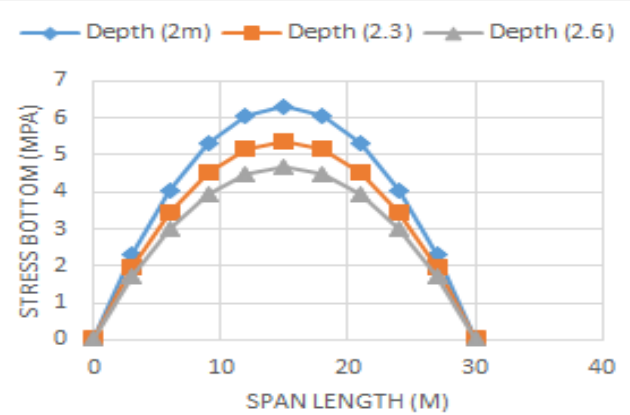

Fig. 31. Comparison of longitudinal stress at bottom flange for the rectangular hollow girder under (DL)

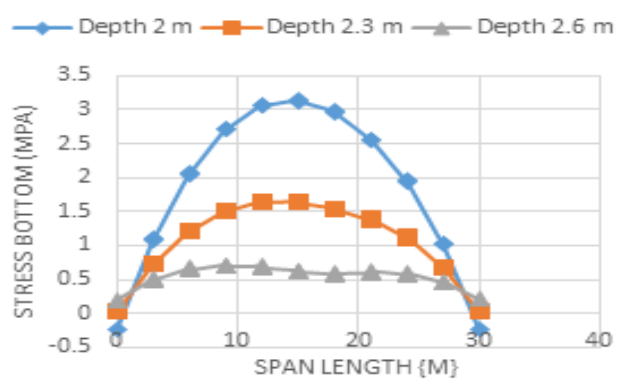

Fig. 33. Comparison of longitudinal stress at bottom flange for therectangular hollow girder under (DL+P+LL)

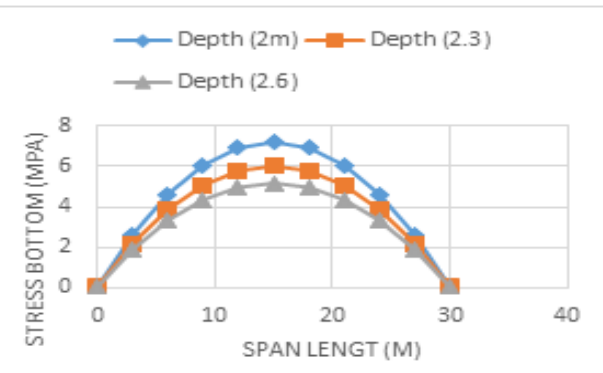

Fig. 35. Comparison of longitudinal stress at bottom flange of the (Sloped) hollow girder under (DL)

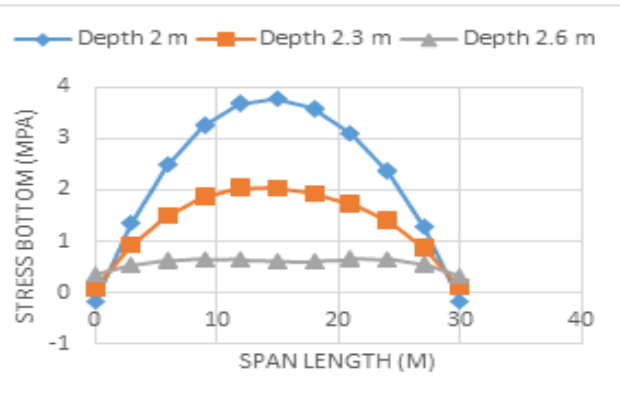

Fig. 37. Comparison of longitudinal stress at bottom flange of the (Sloped) hollow girder under (DL+P+LL) 


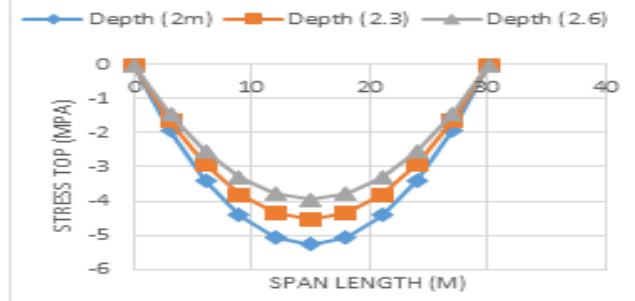

Fig. 38. Comparison of longitudinal stress at top flange of the (Max Sloped) hollow girder under (DL)

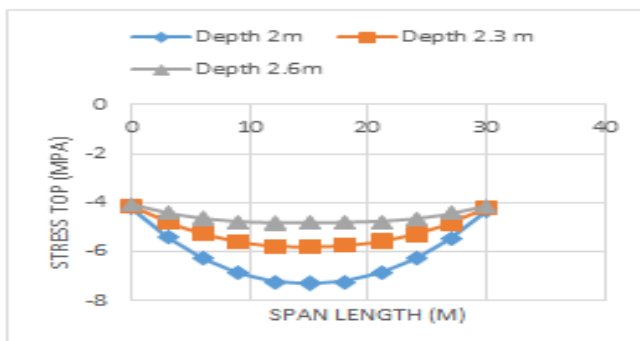

Fig. 40. Comparison oflongitudinal stress at top flange of the ( Max Sloped) hollow girder under (DL+P+LL)

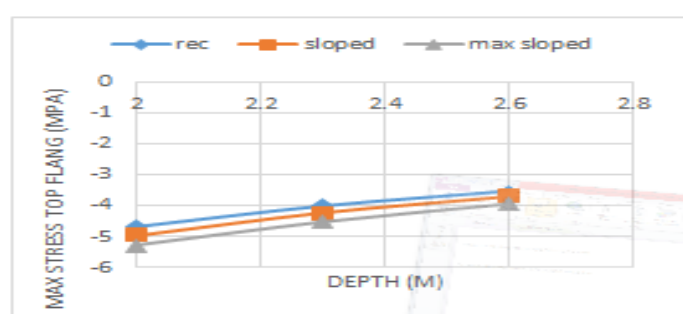

Fig. 42. Maximum longitudinal stress at mid span of top flange under (DL) against girder depth

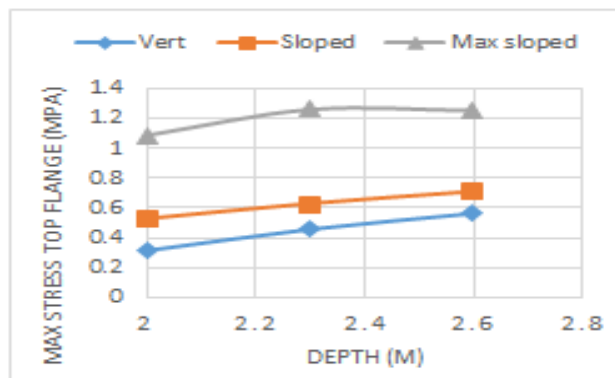

Fig. 44. Maximum longitudinal stress at mid span of top flange under $(P)$ against girder depth

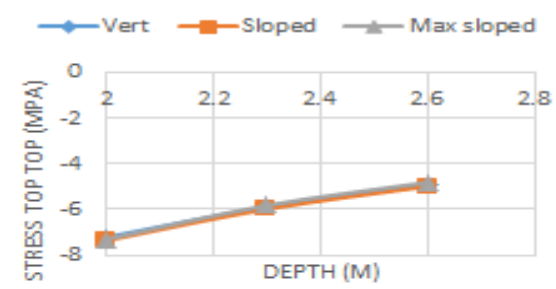

Fig. 46. Maximum longitudinal stress at mid span of top flange under (DL+P+LL) against girders depth

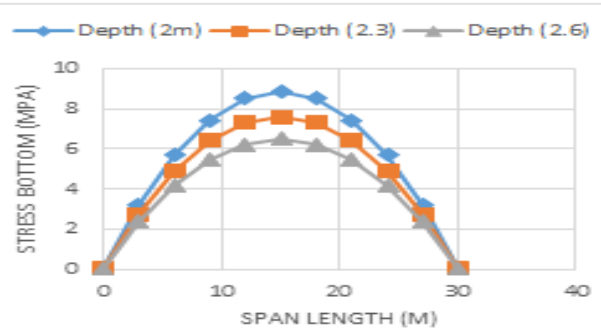

Fig. 39. Comparison of longitudinal stress at bottom flange of the (Max Sloped) hollow girder under (DL)

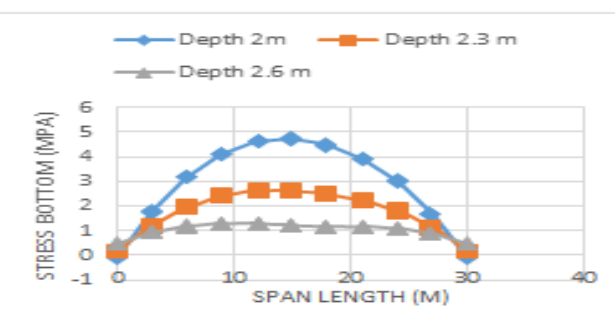

Fig. 41. Comparison of longitudinal stress at bottom flange of the (Max Sloped) hollow girder under $(\mathrm{DL}+\mathrm{P}+\mathrm{LL})$

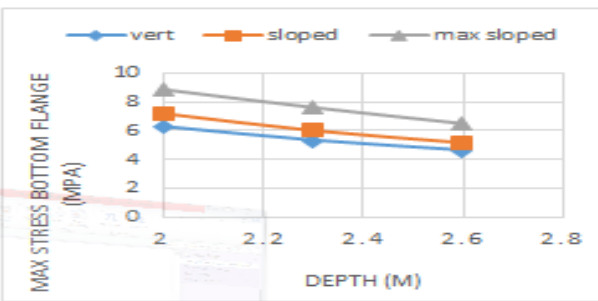

Fig. 43. Maximum longitudinal stress at mid span of bottom flange under (DL) against girder depth

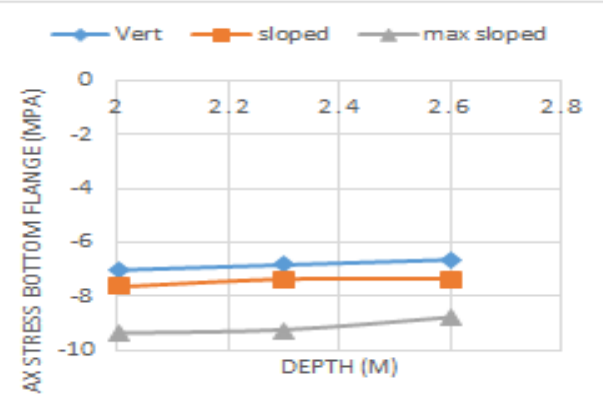

Fig. 45. Maximum longitudinal stress at mid span of bottom flange under $(\mathrm{P})$ against girder depth

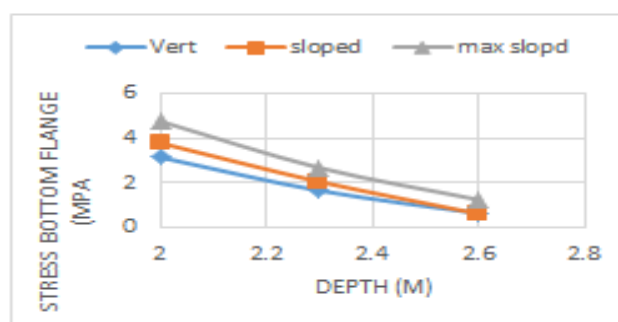

Fig. 47. Maximum longitudinal stress at mid span of bottom flange under (DL+P+LL) against girders depth 
From the above results, it is observed that the deflection at mid span and longitudinal stress along span length of hollow girders under dead load, pre-stressed load and moving live load decrease as the depth of the cross girder increases. There is no significant variation in the maximum longitudinal stresses at the bottom flange under prestressing load (P) with different depths. The deflection and longitudinal stress at top and bottom flange are the least for rectangular section under all cases of loading.

\section{Conclusions}

The analysis of multi-cell hollow girder rectangular (Vert), trapezoidal (With exterior girder slopped), and trapezoidal (With exterior girder maximum slopped) are carried out using CSI- Bridge program. The results presented here highlight the effects of slope of exterior girder of the hollow girder with three cells on the behaviour in terms of deflection and longitudinal bending stresses. Based on the obtained results in this research and within the range of variables considered here, the following conclusions can be drawn:

1) The deflection as well as bending stress are lowest in bridges having rectangular hollow girder.

2) The deflection and stress in bridge having hollow girder decreases as the depth of this girder increases.

3) It can be considered that stiffness and strength of the bridges having rectangular hollow girder are more when compared to the trapezoidal (With slopped exterior girder) and trapezoidal (With exterior girder maximum slopped).

\section{REFERENCES}

[1] Egyptian Code for Loads and Forces on Buildings and Structures, EC 201, 2012.

[2] Ibrahim A. and Salim H. "Finite-element analysis of reinforced concrete box girder bridges under close-in detonations", Journal of Structural Engineering ASCE, No.10.1061 (2013), pp. 1943-5509.

[3] Venkata Siva Reddy, P. Chandan Kumar. "Response of box girder bridge spans " International Journal of Bridge Engineering (IJBE), Vol. 2, No. 2-2014

[4] Chetan T Naik1,.M M Achar, K Lakshmi "Analysis and Design of Multi Cell PostTensioned PSC Box Girder" IOSR Journal of Mechanical and Civil Engineering (IOSRJMCE) Volume 12, Issue 4 Ver. VII (Jul. - Aug. 2015), PP 56-64

[5] Harish M K, Chethan V R, Ashwini "Analysis and behavioural investigation of box girder bridges" 2017 IJRTI Volume 2, Issue 9 ISSN: 2456-3315

[6] 6)Amit Upadhyay Dr. Savita Maru "Comparative Study of PSC Box Girder Multi Cell (3Cell) Bridge of Different Shapes" International Journal for Research \& Development| Vol. 5, Issue 03, 2017

[7] Prajwal Raj1, Mr.Vasantha.D2 "Structural behaviour of box girder bridge using Csi Bridge 2015" " International Research Journal of Engineering and Technology (IRJET) V 04 Issue: 04 Apr -2017

[8] Kiran Kumar Bhagwat, D. K. Kulkarni, Prateek Cholappanavar "Parametric study on behaviour of box girder bridges using CSi Bridge" International Research Journal of Engineering and Technology (IRJET) V 04 Issue: 08 Aug -2017. 
سلوك الكبارى الخرسانية سابقة الاجها ذات قطاعات صندوقية ثلاثية الخلايا

الملخص العربي:

تعرف الكباري الخرسانية الصندوقية سـابقة الاجهاد بثباتها وتميز هـا و ادائها الجيد و لان سلوك الكبان الكباري

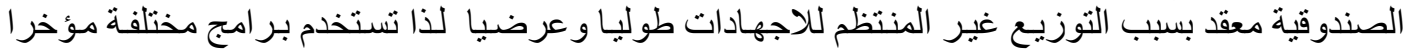

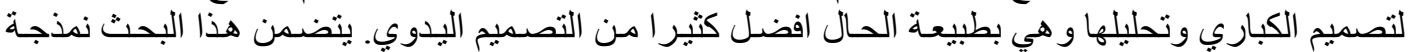

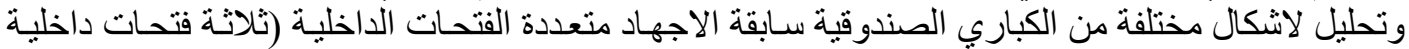

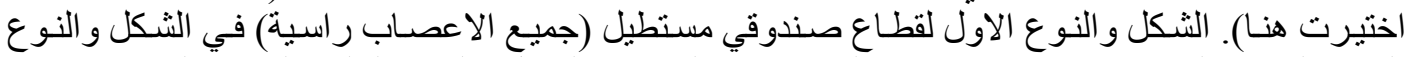

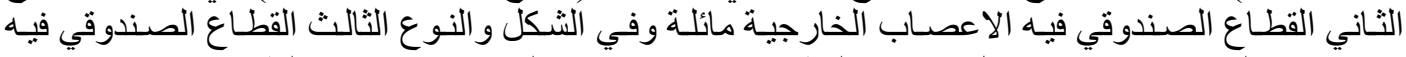

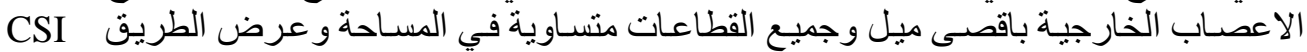

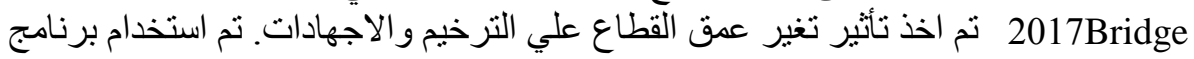

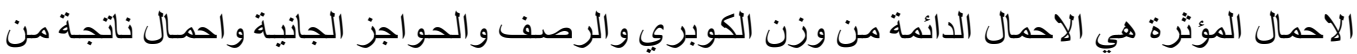

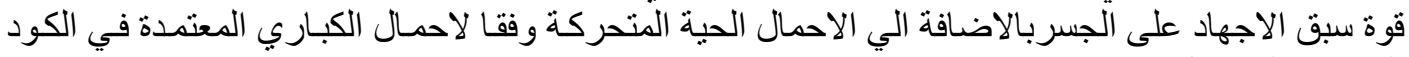
المصري للاحمال .

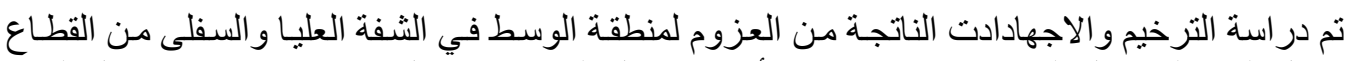

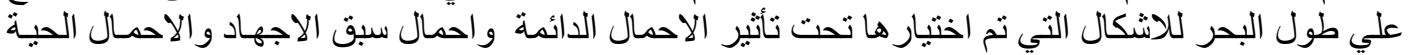

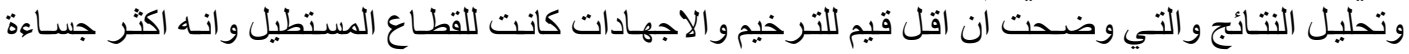

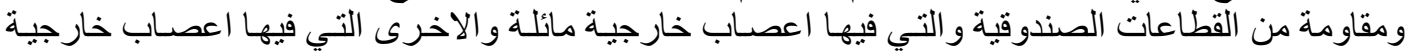

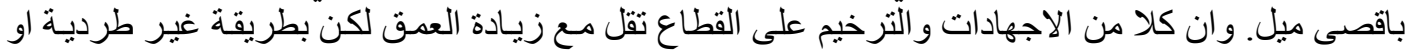

